\title{
Lichens and their Action on the Glass and Leadings of Church Windows.
}

By Dr. Ethel Mellor, University College, Reading.

THE gradual deterioration and destruction of the stained glass of church windows is a subject of general and scientific interest. It will, therefore, probably be admitted that the technical and practical knowledge of the stained glass artist should be reinforced by the theoretical and laboratory studies of the scientific worker. One of the several possible lines of research was approached nearly three years ago at the Sorbonne under the direction of the late

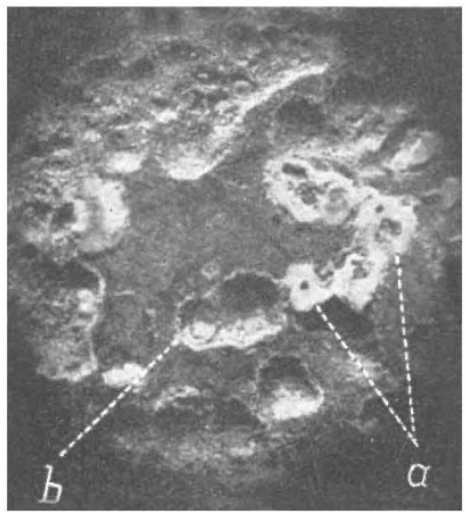

FIG. 1. $\left(\times_{36 .}\right)$

(a) Opaque discs with beginnings of pits; (b) pit bordered by opaque glass.
Prof. Matruchot and afterwards of the late Prof. Bonnier.

The deteriorated glass is scaly and iridescent, or pitted and opaque. Both surfaces are attacked, and though the outer shows the greater alteration, it is on the inner that the action is sometimes first apparent. The opacity may extend over the whole surface, but more frequently appears as scattered disc-like points; these gradually get bigger and frequently run together. Meanwhile, the glass at the centre of the original opaque discs disappears and so arise the beginnings of the pits, each bordered by opaque glass and later lined by iridescent scales visible under the binocular lens. As the alteration of the glass continues, the pits increase in diameter and often unite, forming channels of diverse outline and length (Fig. I). The maximum breadth measured was $5 \mathrm{~mm}$., and depth $\mathrm{r} \cdot 9 \mathrm{~mm}$. Two pits on opposite surfaces will sometimes increase in depth until the separating wall disappears and a perforation of the glass results. Microscopical examination of the opaque glass shows markings and surfaces similar to geographical contours, and the contortions and cleavages of rocks.

In some cases there is no opacity, and there are no pits. The surface is iridescent and may appear slightly irregular over more or less extended areas. The alteration here takes the form of scaling in thin horizontal plates shown under the microscope to consist of several superposed layers variously cleft and resembling a crazy-tiled garden path.

Unstained and stained glass are similarly deteriorated, but certain colours show more susceptibility to alteration than others. Purple, green, blue, red, amber, and particularly amethyst glasses, are all deeply corroded, while grey tones are less so, and the golden-yellow glass resulting from the vitrification of the silver salts is more or less immune. This immunity is well illustrated in the reproduction of a fragment of fifteenth-century glass (Fig. 2); the surface of the grey and colourless portions is corroded and opaque, and outlines clearly the golden-yellow border and leaf.

There is little reason to believe that the glass of any century is the more frequently or gravely attacked. The glass of the twelfth to the fifteenth centuries is more refractive than that used later and shows a slower rate of alteration, but the cumula- tive destructive effects are great. The extent of the corrosion does not depend upon age-portions of fourteenth-century glass are still unaltered; specimens of nineteenth-century glass are sometimes badly pitted. The corrosion is of considerable importance æsthetically, but, though it continue until perforation occurs, it does not affect the actual duration of the window; this depends upon the leadings.

The oldest leadings are heavy and have well resisted chemical change; the lighter lead used since the fifteenth century is much more liable to conversion into carbonate of lead, friable and unstable. The transformation is often completed in less than fifty years. This is a matter of supreme importance, for the leadings constitute the skeleton of the window and their appearance remains reassuring after the chemical change has taken place. They are, however, no longer solid, and the crucial moment arrives when an external condition, such as a gust of wind, causes them to disaggregate and allow the glass to fall. It is in this way that so many of the marvellous windows of the last few centuries have perished. This destructive process has been studied and pointed out repeatedly during the last thirty years by M. Félix Gaudin of Paris, a wellknown peinte-vervier; it cannot be emphasised too much that it is through the leadings and not through the glass that historic windows are often lost.

The alteration of the lead is purely chemical; that of the glass is due to two causes, chemical and mechanical. Strange though it may seem, the windows serve as a substratum for lichens. These plants retain water between their tissues and the glass by capillarity; they also find favourable conditions for growth in proximity to the leadings, which check the drainage where they approach the horizontal plane, and when loose hold water. The amount of carbon dioxide normally dissolved in water is considerably increased by that evolved by the lichens

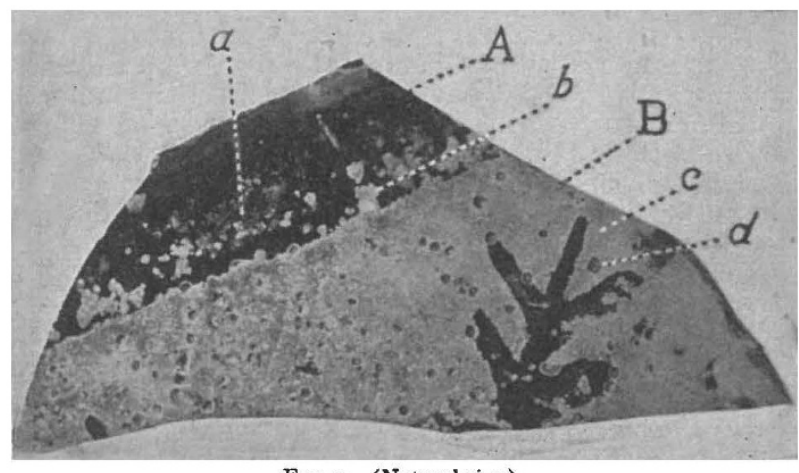

FIG. 2. (Natural size.)

A, Golden-yellow glass: (a) scaly glass; $(b)$ opaque glass. B, Grey and colourless glass: $(c)$ opaque surface; $(d)$ pit.

during the process of respiration, and the chemical change of glass and lead is thus accelerated. Evidence of this augmentation of the chemical action is given by the opacity and squamosity of the glass closely following the track of the lichen.

The mechanical action of the lichens accounts for the disappearance of the opaque glass, and the consequent formation of pits and channels. The minute fissures in the opaque glass are penetrated by the lichen hyphæ, which by their varying states of 
turgidity, and increase in length and number, loosen the particles and eventually incorporate them in their tissue. The inclusions, always microscopic, occur chiefly in crustaceous thalli below the apothecia and spermogonia, and in the rhizoids of the foliaceous thalli. Vertical sections of the thallus of a Pertusaria leucosora Nyl. contained numerous inclusions throughout the lower $0.4 \mathrm{~mm}$. of their thickness.

The inner surface of the glass is the one most frequently squamose. The conditions here are most unfavourable for the development of lichens and usually there is no delimitation of the thallus. The



(a) Placodium murorum DC. and circular pit; (b) corrosion showing outlines of original pits.

lichen constituents, hyphæ and gonidiæ, are not associated in a definite tissue but exist as a thin layer, resembling a cobweb, over more or less the whole surface, which shows a similar extensiveness in its alteration. Hyphæ and gonidiæ pass between the scales of glass, the former the more deeply, and incorporation follows.

The lichen flora of church windows is practically confined to the exterior, and necessarily limited by the exposed and slippery substratum. Twenty-three species and varieties have been identified, including only one fructaceous, Ramalina polymorpha Ach. var. ligulata Ach., and two foliaceous, Xanthoria parietina Ach. and its variety tumida Wed. All the others are crustaceous, these being the best adapted to the environment. There appears to be a succession in the flora analogous to that on a larger scale of the flora of dunes in so far as there is a preparation of the substratum for subsequent species of lichens. A crustaceous species, Diploicia canescens Ach., is the most abundant but it rarely occurs except on the unaltered glass; its thallus, of a maximum diameter of $4^{\cdot 6} \mathrm{~cm}$., disappears and leaves a slightly roughened surface. Other crustaceous species follow, two varieties of Placodium murorum DC. being most interesting, showing as they do a conformity between their disc-shaped thalli and the circular pits of their substratum (Fig. 3). The crustaceous lichens apparently cease to thrive once the glass becomes deeply corroded, yet it is on this considerably altered surface that the fructaceous and foliaceous species exist (Fig. 4).

The lichens are not well developed. Some are not visible to the naked eye; the thallus is small; mal-formed, incomplete, or greatly soredified; apothecia are frequently absent or, conversely, persist longer than the thallus. Their determination is difficult, and is often only possible through a prolonged and concentrated study of the gradual change undergone by a species.

Lichens need plenty of air and a certain humidity, with little wind or sun, for their free growth; consequently, windows with a south aspect in the country and all windows in a crowded neighbourhood are unfavourable substrata; they have a scant flora or none at all, and show little deterioration. On windows with a west or north aspect, in humid, calm, but airy surroundings, lichens multiply abundantly and quickly, and the glass shows a correspondingly high degree of alteration. The colour or chemical composition of the glass probably influences the development of lichens, as it is not unusual to see glass of one colour bearing many of these small plants while adjacent glass of another colour is free.

Growth of lichens on windows can be prevented by the simple means of regularly brushing and washing the windows, or by the application of a liquid mastic to exclude air and lichen spores. The essential condition for the ultimate preservation of the windows is that the leadings should receive constant attention and periodic renewal.

The material examined has in the bulk been collected by M. Gaudin throughout Brittany, Normandy, Champagne, Ile-de-France, etc. A certain number of specimens from the Mayenne churches submitted by M. Alleaume, peinte-verrier of Laval, are now deposited in the museum of that town.



FIG. 4. $(\times 2$.

(a) Circular pit; (b) irregular channel; (c) corroded border of glass originally inserted in leadings; $(d)$ transparent surface; $(e)$ lichen debris ; (f) Xanthoria parietina Ach.; $(g)$ Placodiunt murorum $\mathrm{DC}$.

Mellor, E.--Notes sur les Lichen vitricoles : Comptes rendus de la Société Biologique de France, I92I.

Les Lichens vitricoles et leur action mécanique sur les vitraux d'église: Comptes rendus, Académie des Sciences, t. I73, 28 novembre I92I.

Thèse-Les Lichens vitricoles et la détérioration des vitraux d'église: Paris I922.

Summary of Thesis: Revue générale de Botanique, Paris I922.

Mellor, E. and Virville, Ad. Davy de.-La Détérioration des vitraux d'église de la Mayenne par les Lichens : Bulletin de Mayenne-Sciences, r922. 